\title{
¿HUBO CHECAS EN EL MADRID DE LA GUERRA CIVIL? ESTUDIO COMPARADO DE LA POLICÍA POLÍTICA SOVIÉTICA Y LOS COMITÉS REVOLUCIONARIOS ESPAÑOLES (VERANO-OTOÑO 1936)
}

\author{
Were there "Checas" in the Madrid of the Civil War? Comparative study of \\ the Soviet political police and the Spanish revolutionary committees \\ (summer-autumn 1936)
}

\author{
Fernando Jiménez Herrera \\ Universidad Complutense de Madrid \\ fernandojimenez@estumail.ucm.es
}

Recibido: 05-06-2018 - Aceptado: 17-10-2018

Cómo citar este artículo/Citation:

Fernando JIMÉNEZ HERRERA, "iHubo Checas en el Madrid de la Guerra Civil? Estudio comparado de la policía política soviética y los comités revolucionarios españoles (verano-otoño 1936)", Hispania Nova, 17 (2019), págs. 49-84,

DOI: https://doi.org/10.20318/hn.2019.4516
Copyright: (c) HISPANIA NOVA es una revista debidamente registrada, con ISSN I I38-73I9 y Depósito Legal M 9472-1998. Los textos publicados en esta revista están -si no se indica lo contrario- bajo una licencia Reconocimiento-Sin obras derivadas 3.0 España de Creative Commons. Puede copiarlos, distribuirlos y comunicarlos públicamente siempre que cite su autor y la revista y la institución que los publica y no haga con ellos obras derivadas. La licencia completa se puede consultar en: http://creativecommons.org/licenses/by-nd/3.0/es/deed.es
Resumen: Ante el fenómeno inesperado que tuvo el golpe de estado y la derrota de la sublevación sobre el Estado republicano, surgieron toda una serie de micropoderes que intentaron y compitieron entre sí por ocupar el espacio que había dejado vacío el Gobierno. Estos micropoderes, comités revolucionarios en su mayoría, no solo persiguieron ganar la guerra, sino iniciar y asentar un proceso revolucionario, contrapuesto al modelo de estado Republicano. Estos centros, al ejercer la justicia popular, fueron catalogados por los sublevados como "checas", ligando su imagen al modelo de policía política soviético, la Cheká. En este trabajo se va a analizar el término checa, comparando los dos sistemas, el ruso y el español, para valorar si este concepto ayuda o entorpece nuestra comprensión sobre un fenómeno tan complejo como fue el de la revolución.

Palabras Clave: Guerra civil, Cheká, Violencia, comités, Madrid.
Abstract: Faced with the unexpected phenomenon of the coup d'état and the defeat of the revolt against the republican state, a whole series of micro-powers arose that tried and competed with each other to occupy the space left by the government. These micropowers, revolutionary committees for the most part, not only sought to win the war, but to initiate and settle a revolutionary process, as opposed to the Republican state model. These centers, in exercising popular justice, were labeled by the insurgents as "Checa", linking their image to the Soviet political police model, the Cheká. In this paper we will analyze the Cheká term, comparing the two systems, Russian and Spanish, to assess whether this concept helps or hinders our understanding of a phenomenon as complex as the revolution.

Keywords: Civil war, Cheká, Violence, committees, Madrid.. 


\section{INTRODUCCIÓN}

Durante la guerra civil hubo un término que se hizo tremendamente popular. Este término fue el de "checa". Tanto es así que, como dice Hugo García, "no hay relato ambientado en Madrid que no incluya su checa, normalmente descrita como un sótano tétrico y siniestro que sirve de cámara de tortura a milicianos sucios y malvados". ${ }^{1}$ Pero ¿A qué hace referencia este concepto? Entre los historiadores expertos en la materia no hay una definición unánime. Encontramos diversas acepciones para este término, como es el caso de Javier Cervera Gil, quién utiliza la definición de Peter Wyden, "la palabra checa se usó en toda España para referirse a los temidos tribunales (muchas veces autodesignados) que surgieron en muchas vecindades a fin de eliminar al "enemigo fascista", a menudo por medio de denuncias de escasísima fiabilidad."2 Paul Preston, en su libro El Holocausto Español define a las checas de la siguiente manera: "Estos escuadrones [los encargados de las ejecuciones], así como sus tribunales y sus prisiones, eran las famosas "checas"." Es decir, recurriendo a dos definiciones de dos historiadores fundamentales dentro del estudio de Madrid durante la guerra civil nos ofrecen dos definiciones diferentes. Mientras que, por un lado, Javier Cervera Gil, al recurrir a Peter Wyden, hace alusión a los tribunales autodesignados, Paul Preston, por otro lado, amplia la definición y encuadra bajo ese término a toda la estructura que compuso esos espacios, no solo tribunales, sino también sus "escuadrones", y el espacio en sí. En lo que coinciden ambos autores es en la relación del término checa con la violencia revolucionaria que aconteció en los primeros meses de la contienda en la retaguardia republicana.

No obstante, esta pregunta nos lleva a otras como ¿Cuándo surgió el término? ¿Se autoproclamaron checas o fue un nombre (im)puesto desde fuera? Si no fueron sus protagonistas los que asumieron ese concepto para definirse a sí mismos y a sus funciones

\footnotetext{
${ }^{1}$ Hugo GARCÍA: "Relatos para una guerra. Terror testimonio y literatura en la España nacional," Ayer, 76, 4 (2009). p. 168.

2 Javier CERVERA GIL: Madrid en guerra. La ciudad clandestina, 1936-1939. Madrid, Alianza, 2006. p. 64.

${ }^{3}$ Paul PRESTON: El Holocausto español. Odio y exterminio en la Guerra Civil y después. Barcelona, Debate, 2011. p 357.
} 
¿Quién se lo llamo y por qué? Estas son las preguntas que guían el siguiente trabajo, con el objetivo de responder a la pregunta que da nombre a este artículo ¿Hubo checas en la guerra civil española? Para poder responder a esta pregunta y a las anteriormente formuladas se va a recurrir al estudio de este término, dónde surgió y por qué para después analizar cómo llegó a España y qué se interpretaba por checa antes de la guerra. Posteriormente, se estudiarán los centros que recibieron ese nombre, para finalizar este trabajo comparando ambos sistemas y valorando si es útil, o no, el concepto "checa" para comprender la retaguardia republicana durante la guerra civil española. Dentro de los múltiples micropoderes que surgieron en la retaguardia republicana se estudiaran aquellos centros que fueron conocidos por el concepto checas para la ciudad de Madrid, es decir, los comités revolucionarios. Quedan fuera de este estudio, organismos como el CPIP, las MVR, el DEDIDE o el SIM, ${ }^{4}$ al exceder los objetivos temporales y espaciales de este trabajo. Un estudio integral de semejante envergadura requeriría de un monográfico, más que un artículo. El objetivo de este trabajo, por tanto, es poner en cuestión un concepto, que se ha mostrado incapaz de definir con claridad un acontecimiento tan complejo como fue el de los comités madrileños del verano otoño de 1936 que dieron lugar a la apertura de un proceso revolucionario, siguiendo así el ejemplo de otros historiadores para conceptos como "incontrolados", "persecución religiosa", "forastero" o "fascista" ${ }^{5}$

\section{LA COMISIÓN PAN-RUSA EXTRAORDINARIA DE LUCHA CONTRA LA CONTRARREVOLUCIÓN, LA ESPECULACIÓN Y EL ESPIONAJE, CHEKÁ}

El 20 de diciembre de 1917 se creó la "Vserossiskaya Cherezvitchainaia komissia po borby s kontrrevoliutsii, spekuliatsei i sabotagem", en castellano, "Comisión Pan-rusa Extraordinaria de lucha contra la Contrarrevolución, la Especulación y el Espionaje". Las siglas en ruso fueron las que generaron el acrónimo Cheká, aunque también fue conocida bajo el nombre de "Comisión". La Cheká, fue una institución donde prevaleció el carácter

\footnotetext{
${ }^{4}$ El Comité Provincial de Investigación Pública (CPIP), las Milicias de Vigilancia de Retaguardia (MVR), el Departamento Especial de Información del Estado (DEDIDE) y el Servicio de Información Militar (SIM).

${ }^{5}$ Maria THOMAS: La fe y la furia. Violencia anticlerical popular e iconoclastia en España, 1931-1936. Granada, Comares, 2014; Assumpta CASTILLO CAÑIZ: "El forastero en la guerra civil española. Las dinámicas intra y extracomunitarias de la violencia en la retaguardia republicana," en Revista Universitaria de Historia Militar 6, vol. 3, 2014; José Luis LEDESMA: Los días de llamas de la revolución: violencia y política en la retaguardia republicana de Zaragoza durante la guerra civil, Institución Fernando el Católico, Zaragoza, 2004.
} 
policial y judicial antes que el político, por la situación de vacío institucional producido por la descomposición espontánea y el desmantelamiento deliberado del viejo sistema judicial. ${ }^{6} \mathrm{EI}$ borrador que dio origen a esta institución se caracterizó por la exposición de unas directrices amplias y mal definidas que confirieron a la Comisión grandes atribuciones represivas. Todo este proceso fue acompañado por una renovación total de los tribunales existentes. Se suprimieron los tribunales del antiguo régimen para dar paso a tribunales populares y tribunales revolucionarios. Unido todo ello a un proceso de renovación dentro del campo jurídico. ${ }^{7}$

Al frente de esta institución se puso a Félix Dzerzhinski, una de las personas de mayor confianza de Lenin y un bolchevique respetado entre sus camaradas. ${ }^{8}$ Fiel defensor de la institución que ayudó a crear, fomento su expansión por todo el territorio ruso e insistió ante el Partido y el Gobierno en la conservación de la de la Cheká y la necesidad de dotarla de atribuciones que le permitiesen ejercer su función sin escollos. Prueba de ello fue el rápido crecimiento de la Comisión. Aunque, también hay que decir, que su desarrollo no se debió en exclusiva al entusiasmo de su líder frente a los detractores dentro del Gobierno, sino que también se debió al "favorable" contexto de guerra civil, donde se hizo imprescindible, según sus partidarios, un brazo armado en la retaguardia que proteja al Estado de saboteadores y contrarrevolucionarios. Otro factor a tener en cuenta, y que retroalimenta al anterior, fue el miedo producido en los gobernantes ante el avance de las tropas alemanas en su frente oriental. Este temor al invasor exterior $y$ al interior facilitada su acción al producir que el Gobierno reforzase sus brazos armados, tanto el exterior, con la creación del ejército rojo por Trotski, como el interior con la policía política de Dzerzhinski. Desde el cuartel general se confeccionó toda una "red de checas locales, provinciales y de distrito"9 para poder llevar a cabo su función de control de la retaguardia. En este proceso de expansión, la Comisión contó con la ayuda de algunos soviets, que por orden de Dzerzhinski, debian "buscar, arrestar y fusilar de inmediato" a todas aquellas personas

\footnotetext{
${ }^{6}$ Arno J. MAYER: Las Furias. Violencia y terror en las revoluciones francesa y rusa. Zaragoza, Prensa de la Universidad de Zaragoza, 2014. p. 296.

7 Nicolas WERTH: Un Estado Contra su Pueblo. Violencia, Temores y Represiones en la Unión Soviética. Edición electrónica: 2011. http://www.laeditorialvirtual.com.ar. p. 13.

${ }^{8}$ Sheila FITZPATRICK: El equipo de Stalin. Los años más peligrosos de la Rusia soviética, de Lenin a Jrushchov. Barcelona, Crítica, 2016. p. 37.

${ }^{9}$ Arno J. MAYER: Las Furias... p. 268.
} 
sospechosas de ser o llevar a cabo funciones contra la revolución. ${ }^{10}$ Además de formar sus propias divisiones, las chekas locales debían enviar a la central, instalada en la calle Lubianka de Moscú, toda la información sobre organizaciones y personas sospechosas. También Dzerzhinsky dispuso que se formasen tribunales revolucionarios para investigar y enjuiciar los delitos cometidos contra el Estado. ${ }^{11}$

En relación a su funcionamiento interno, la Cheká careció de procedimientos internos sobre su actuación con los detenidos o sobre como recabar pruebas que los incriminasen o los absolviesen. No hubo instrucciones que dictasen la actuación de los agentes en una investigación, ni los modelos que debían seguir las denuncias o las pruebas recabadas por los agentes. Aun así, la apelación de los detenidos ante las detenciones no fue posible. En el procedimiento judicial, las bases para su regulación fueron escasas y mal definidas, y, aunque se les permitió contar con abogados defensores, de poco sirvieron. Las resoluciones podían ser de libertad, cárcel, multa o la pena capital. ${ }^{12}$ Los Tribunales Revolucionarios fueron una respuesta del Estado ante la ausencia de un sistema judicial, como la Cheká ante la ausencia de fuerzas del orden leales a la revolución bolchevique. Fueron una parte del sistema, no un todo, ya que existieron otros tipos de tribunales como los Populares, cada uno con atribuciones específicas. En el caso de los Tribunales Revolucionarios fueron los encargados de juzgar los delitos contra el Estado. La actividad de la Comisión no estuvo ligada a ninguna norma jurídica de procedimiento, por lo menos en relación a la detención y arresto. Las ejecuciones estuvieron limitadas a las insurrecciones armadas, actividad contrarrevolucionaria y bandidaje. ${ }^{13}$

Alcanzada la paz con los alemanes con el tratado de Brest-Litovsk el 3 de marzo de 1918, el enfrentamiento interior no dejaba pie al descanso. La contrarrevolución tomaba cuerpo formando el ejército blanco. El escenario seguía siendo propicio para la actuación de la Cheká y su lucha contra el enemigo de la revolución en medio de la guerra civil. Sus objetivos fueron, generalmente, miembros de los colectivos que tradicionalmente se habían mostrado contrarios a los bolcheviques y su revolución. Se castigó la disidencia, e incluso,

\footnotetext{
10 James HARRIS: El gran miedo. Una nueva interpretación del terror en la Revolución rusa. Barcelona, Crítica, 2017. p. 37.

${ }^{11}$ Arno J. MAYER: Las Furias... pp. 295-296.

12 James HARRIS: El gran miedo... p. 37.

${ }^{13}$ Arno J. MAYER: Las Furias... p. 326.
} 
las opiniones desfavorables a las medidas adoptadas por el ejecutivo, por considerarlo los bolcheviques contraproducente para el desarrollo bélico. Prueba de este cambio de parecer fue que a partir de abril-mayo de 1918 se clausuraron periódicos y revistas que no fuesen afines al Partido o la actuación del Gobierno, incluyendo medios de sus antiguos socios como socialistas revolucionarios y anarquistas.

La Cheká llevo a cabo detenciones, por lo general, a altas horas de la noche, a políticos, periodistas, académicos y abogados, entre otros, acusándoles de pertenencia a grupos contrarrevolucionarios. Otro de los grupos que tuvo un mayor índice de detenciones por parte de la Comisión fueron los propietarios de las industrias y terratenientes del país, también llamados por los bolcheviques “capitalistas”. El principal temor no era el cierre de las industrias, sino los actos de sabotaje que podían producir la bajada de la producción o la mala comunicación y transporte de mercancías. El problema venía de todos los grupos de ingenieros, capataces o administradores que no tuvieron la oportunidad de irse y que no eran partidarios del gobierno.

Además, se incrementó el número de denuncias por la tradicional hostilidad entre el cuerpo administrativo y los trabajadores. ${ }^{14}$ Pero muchas de estas suposiciones no fueron desencaminadas, ya que las fuerzas blancas intentaron favorecer la actividad de quintacolumnistas que dificultasen la actividad económica y redujesen la producción. Sin embargo, la actuación de la Comisión que causó un mayor impacto fue la ejecución del Zar Nicolás II y su familia el 17 de julio de 1918, fecha en la que los enfrentamientos en la guerra civil se estaban intensificando y el Gobierno se veía cercado por las derrotas y los actos de sabotaje y contrarrevolucionarios. ${ }^{15}$ Sin embargo, la represión ejercida por el Estado a través de la Cheká no se limitó a todas aquellas clases sociales y grupos políticos discordantes con los bolcheviques, sino también, contra sus antiguos aliados circunstanciales, como fueron los Socialistas Revolucionarios o los anarquistas. La oposición de ambos grupos hacia diversas medidas emprendidas por el Gobierno, como el tratado de paz de Brest-Litovsk o el control de la producción por el Estado, produjo que los sucesivos gabinetes calificasen de enemigos a sus antiguos aliados y consideró una amenaza cualquier disidencia y crítica contra el Gobierno, lo que dilo lugar a la clausura de

\footnotetext{
${ }^{14}$ James HARRIS: El gran miedo... pp. 45-46.

${ }^{15}$ Arno J. MAYER: Las Furias... pp. 315-316.
} 
periódicos o la detención de sus militantes y líderes, obligando a estos grupos a pasar a la clandestinidad o al exilio. ${ }^{16}$

Las acusaciones pudieron ser a nivel individual, por suponer al detenido actividades subversivas, o realizadas en colectivo, como las conspiraciones. La Cheká no contó con tiempo suficiente ni medios para poder llevar a cabo investigaciones sobre los detenidos, por lo que, en general, "detuvieron primero y preguntaron después." Uno de los errores más comunes de la Cheká fue interpretar numerosas detenciones como parte de una conspiración mayor orquestada desde las filas blancas. La cheká se aficionó a arrogarse el destapar conspiraciones como "el consejo de activistas públicos", "la unión de los terratenientes" o "el centro derechista."17 Dzerzhinsky exageró el alcance de las conspiraciones, aunque destrozó varias camarillas simpatizantes de los blancos en el otoño invierno de $1918-1919,{ }^{18}$ como forma de conseguir mayor influencia y poder para la organización que dirigía.

Sin embargo, aunque la Comisión se esforzaba por frenar la extensión de las insurrecciones contrarrevolucionarias, la situación de los bolcheviques dentro de la guerra civil se agravaba, haciendo peligrar la revolución. Ante semejante situación, el Gobierno optó, en el verano de 1918, por la estrategia del terror como agente paralizante de la actividad contrarrevolucionaria. No obstante, el ejecutivo no legalizó y aplicó de forma sistemática el terror hasta el 4 de septiembre, fecha en la que se aprobó el decreto que le daba origen. Los casos anteriores, fueron esporádicos, relacionados con algún detonante inmediato vinculado a acciones específicas del ejercito enemigo o de las conspiraciones internas. ${ }^{19}$ A partir de ese momento, todas las fuerzas represivas del sistema bolchevique, incluida la Cheká, pasaron directamente a la ejecución sumaria, sin valorar pruebas o realizar interrogatorios. Los sospechosos pasaron a campos de concentración o a la ejecución. Las prácticas selectivas se quedaron atrás frente a los registros y arrestos

\footnotetext{
16 Julián VADILLO MUÑOZ: Por el pan, la tierra y la libertad. El anarquismo en la Revolución rusa. Guadalajara, Volapük, 2017. p. 174.

17 James HARRIS: El gran miedo... p. 45; y pp. 53-54.

${ }^{18}$ Arno J. MAYER: Las Furias... p. 339.

${ }^{19}$ Ibídem, pp. 322-324.
} 
masivos, potenciando la guerra de clases. $^{20}$ Similares tácticas de terror adoptaron los ejércitos blancos. Tácticas que se mantuvieron hasta el final de la guerra en 1921.

El terror rojo en la guerra civil no fue una constante en el tiempo y el espacio, sino que fue fluctuando en función de los acontecimientos. El devenir de la guerra o el atentado a autoridades, marcaron los picos y bajadas en los niveles represivos de los aparatos del Estado. ${ }^{21}$ Otra de las fuentes que nutrieron el terror estatal fueron los relatos de los evadidos y refugiados que huían del terror blanco. En la mayor parte de Rusia el terror estuvo relacionado con los ejércitos en liza. ${ }^{22} \mathrm{El}$ terror fue mucho más parte de operaciones militares que batallas políticas contra enemigos y conspiradores, fuera estos reales o imaginados. Aunque en los discursos de los dirigentes bolcheviques primaba un lenguaje de lucha de clases. Por lo tanto, el terror fue aplicado como elemento disuasorio de la actividad contrarrevolucionaria, y ante reveses militares, por lo que tuvo un carácter salvaje y funcional. En este proceso se les otorgó carta ancha a los centros locales de la Comisión. $^{23}$

Los bolcheviques recuperaron viejos métodos de control criminal y político utilizados por el zarismo. Un ejemplo, fueron los campos de concentración y de trabajo que formaron parte de sistema de seguridad interna del sistema bolchevique casi desde el inicio de la guerra civil. El modelo de campo ruso se inserta dentro de la guerra civil rusa, altamente ideologizada, dando lugar a un elevado número de presos políticos. En relación a los campos de trabajo, estos tuvieron una mayor relación con la preparación del escenario bélico que con labores de reconstrucción o de interés económico. Dentro del repertorio de trabajos llevados a cabo por los presos estuvo, por ejemplo, el acondicionamiento del frente de batalla escavando trincheras o colocando alambradas. Las motivaciones que llevaron a recuperar este tipo de centros estuvieron más en relación con la guerra que por el deseo de castigo, de explotación del preso y, mucho menos, de exterminio. ${ }^{24}$

Dentro de este contexto, donde la Cheká se vio favorecida por el Gobierno, incrementando sus atribuciones, hubo voces críticas dentro del partido Bolchevique, dando

\footnotetext{
20 José María FARALDO JARILLO: La Revolución rusa: Historia y memoria. Madrid, Alianza, 2017. p. 159.

${ }^{21}$ Arno J. MAYER: Las Furias... p. 360

22 Jacques SADOUL: Cartas desde la revolución bolchevique. Madrid, Turner, 2016. p. 448.

${ }^{23}$ Arno J. MAYER: Las Furias... p. 291; Y pp. 315-316.

${ }^{24}$ Ibídem, pp. 273-275.
} 
lugar a apariciones de Dzerzhinsky frente a diversas instituciones estatales y sus representantes, defendiendo su organización ante aquellos que querían limitar su poder y presupuestos. No obstante, durante los tres años que duro la guerra civil, la Comisión no se vio privada de ninguna de sus funciones ni de sus privilegios. El movimiento bolchevique le otorgó a esta institución un papel central en la defensa de los intereses de la revolución y en su supervivencia, granjeándose una reputación que se mantuvo durante toda la existencia de la URSS, viéndola como "la espada y el escudo de la revolución" y los chequistas serían "los mejores bolchevique". Sin embargo, no tenía que bajar la guardia y quiso arrogarse el mérito de la victoria final contra los enemigos del Estado bolchevique. Justificar su existencia y vender sus logros como forma de convencer de la necesidad de su existencia, ya que siempre hubo un grupo dentro del partido que no simpatizaba con la Comisión. ${ }^{25}$ Estos éxitos ampliaron la influencia de la Cheká. En 1919 se aprobaron una serie de decretos que empoderaron a la Comisión aún más y le confirieron la capacidad de ejercer justicia sumaria sobre una base aumentada de los supuestos anteriores sobre enemigos políticos y sospechosos. ${ }^{26}$

En definitiva, "tanto la checa como el comunismo de guerra estuvieron impulsados por una combinación de pánico, miedo y pragmatismo, mezclado con orgullo desmedido, ideología y voluntad férrea." El funcionamiento y la estructura de la Comisión estuvieron ligados al desarrollo de la guerra civil. La defensa de la retaguardia fue su prioridad frente a otras actividades relacionadas con el crimen ordinario. Desde el cuartel general se confeccionó toda una red de chekas locales, provinciales y de distrito. Poderes mal definidos, contexto de actuación rápida y acciones resolutivas de los chequistas, que eludiendo los controles judiciales y políticos externos, hicieron de las ejecuciones sumarias una práctica habitual. ${ }^{27}$

Reducida la actividad bélica de la guerra civil en pequeños enfrentamientos y conatos con las fuerzas opositoras a los bolcheviques a partir de finales del año 1920, se intensificaba la actividad de la Cheká una última vez antes de su disolución. La guerra civil y el bloqueo internacional habían producido en Rusia una hambruna que avivo la

\footnotetext{
25 James HARRIS: El gran miedo... pp. 48-50; y p. 54.

${ }^{26}$ Arno J. MAYER: Las Furias... pp. 340-343.

${ }^{27}$ Ibídem, p. 268.
} 
movilización campesina en contra del Estado. Estas revueltas tuvieron que ser sofocadas por medio de la fuerza, en el mayor número de casos. ${ }^{28}$ Para ello se recurrieron a las chekás locales, y en los casos más graves, de agentes venidos desde las capitales de provincia o desde la capital. Tras sofocar estas revueltas, y alcanza una mayor estabilidad del estado bolchevique frente a sus opositores internos y externos, se produjo la reforma de la Comisión. Una de las razones por las que se impulsó esta medida fue el creciente descontento dentro del Partido hacia la policía política. Estas presiones se materializaron en el acuerdo de reestructuración de este organismo pactado en diciembre de 1921 en el IX Congreso de los Soviets. El proceso de reforma que finalizó el 6 de febrero de 1922 rebautizándola con el nombre de la Administración Política del Estado (GPU). ${ }^{29}$ Aunque siguió dependiendo administrativamente del Comisariado del Pueblo, el Comisario de Justicia consiguió la potestad para revisar los veredictos dictados por GPU. De esta forma se incrementó el control sobre esta institución. Además de reducir drásticamente las atribuciones de la nueva policía política definiendo mucho mejor sus funciones y reduciendo su personal en los tres años siguientes en un 50\%. ${ }^{30}$ Una medida que respondió a un cambio de situación asociada al abandono del terror y a la extensión de la legalidad de forma paralela a la consolidación de los bolcheviques en el poder. ${ }^{31}$

Detrás de este cambio de nombre, se produjo un cambio importante en el seno del Estado. La Cheká fue, como su propio nombre indica, una comisión extraordinaria, lo que sugería el carácter transitorio de su existencia y de aquello que la justificaba. La GPU indicaba, por el contrario, que el Estado debía disponer de instituciones normales y permanentes de control y de represión políticos. Detrás del cambio de denominación se dibujaban la eternización y la legalización del terror como modo de resolución de las relaciones conflictivas entre el nuevo Estado y la sociedad. ${ }^{32}$ Pero "terror no es lo mismo que la violencia; es, más bien, la forma de gobierno que nace cuando la violencia, tras

\footnotetext{
28 Julián VADILLO MUÑOZ: Por el pan, la tierra y la libertad... pp. 228-229.

29 James HARRIS: El gran miedo... p. 60.

${ }^{30}$ Stuart FINKEL: "An Intensification of Vigilance: Recent Perspectives on the Institutional History of the Soviet Security Apparatus in the 1920s" en Kritika. Explorations in Russian and Eurasian History, 5 (2), 2004. p. 25.

${ }^{31}$ Sheila FITZPATRICK: La Revolución rusa. Buenos Aires, Siglo XXI, 2005. p. 102.

32 Nicolas WERTH: Un Estado Contra su Pueblo... p. 66.
} 
destruir todo el poder, no abdica, sino que, por el contrario, mantiene todo su control." ${ }^{33}$ Aunque la Cheká dejó de existir bajo esa denominación, su recuerdo quedó gravado en la memoria de numerosos protagonistas, periodistas y literatos que hicieron que traspasara fronteras y se mantuviera viva su experiencia a través de sus relatos durante las próximas décadas.

\section{LA POLICÍA POLÍTICA SOVIÉTICA EN ESPAÑA. LA CHEKÁ A TRAVÉS dE LA PRENSA (1931-1936)}

La Revolución rusa tuvo en España poca repercusión. El desarrollo de la Gran Guerra que asolaba Europa centraba la atención de la ciudadanía. La Revolución rusa de febrero (en Europa, marzo) se interpretó dentro del desarrollo del conflicto bélico, generando simpatías entre los aliadófilos y críticas en los germanófilos. Se creía que el nuevo Gobierno provisional ruso apoyaría la guerra y dotaría de mayor coherencia ideológica a la Triple Entente. Sin embargo, también se temía que Rusia firmase la paz con Alemania por separado, influyendo así en el desarrollo del conflicto. Otra creencia que actualmente ha sido descartada por la historiografía, fue la de que detrás de los militares rusos estaba la influencia de Alemania, por lo que nunca Rusia podría haber ganado la guerra. Este rumor de que las autoridades rusas estaban controladas desde Berlín se repitió cuando en octubre (en Europa, noviembre) los bolcheviques iniciaron su revolución, acusándolos de estar bajo el dominio económico germano. Al igual que la anterior suposición, esta fue desmentida por la historiografía. La revolución tuvo un mayor impacto en la prensa europea a raíz del proceso de radicalización de las medidas adoptadas por los sucesivos gabinetes y, principalmente, tras la llegada de los bolcheviques al poder. Este interés por la Revolución tuvo su mayor desarrollo en el arco temporal que transcurre desde 1918 a 1921, aproximadamente, es decir, tras el final de la contienda mundial y con el ascenso bolchevique al poder. Las noticias que venían de Rusia, de mano de agencias europeas, principalmente inglesas y francesas, y los libros de viajes tuvieron una gran repercusión en estos años, generando un debate y opiniones encontradas sobre el proceso que se vivía en el país de los soviets. Aunque, a lo largo de los años veinte decayó el interés por Rusia y su revolución, en 1930 y, sobre todo, a raíz de la proclamación de la

\footnotetext{
33 Julián CASANOVA: La venganza de los siervos. Rusia 1917. Barcelona, Crítica, 2017. p. 156.
} 
Segunda República, Rusia volvió a tener un lugar destacado en los diarios españoles. ${ }^{34}$ Dentro de esta segunda ola de interés por la Revolución rusa y la dictadura del proletariado se inserta el presente apartado, donde se estudia la repercusión de la Cheká en los años treinta en España a través de la prensa.

En la prensa española de los años treinta se recogieron una serie de noticias que informaron de la actividad de la Cheká y que, incluso, se llegó a utilizar para definir la realidad del país. Esta institución fue utilizada por los conservadores en los años de la Segunda República para desprestigiar, principalmente, a colectivos socialistas. La primera referencia aludió a una conferencia celebrada por la Unión Local de Sindicatos de Toledo, en esta ciudad el 26 de diciembre de 1932, a las cuatro de la tarde. Finalizada la conferencia se abrió un turno de preguntas, en la cual un italiano, Angelo Bonirelli (del cual se dice que era anarquista), intervino preguntando sobre el papel del ejército y de la policía política, intervención que no gustó a los comunistas allí reunidos, teniendo que salir escoltado ante una posible agresión. La segunda referencia al término "checa" en la realidad española de los años treinta, fue por parte de un grupo de redactores de El Imparcial hacia su redactor jefe, al que acusaron, a través de una carta que enviaron a diversos periódicos, como $A B C$, de ser un "auténtico mandarín de la Tcheka periodística

\footnotetext{
${ }^{34}$ Para un mejor conocimiento de la influencia de la Revolución rusa en España, se recomienda consultar: Rafael CRUZ: "iLuzbel vuelve al mundo! Las imágenes de la Rusia Soviética y la acción colectiva en España”, en Rafael CRUZ y Manuel PÉREZ LEDESMA (eds.): Cultura y Movilización en la España contemporánea. Madrid, Alianza, 1997. Mikel AIZPURU MURUA: "Ciudadanía e Inmigración. Los exiliados rusos en España (1914-1936)" en Ayer, $\mathrm{n}^{\circ} 78$ (2), 2010. María de los Ángeles EGIDO LEÓN: "Del paraíso soviético al peligro marxista. La Unión Soviética en la España republicana (1931-1936)" en Cuadernos de Historia Contemporánea, $\mathrm{n}^{\circ} 10$, año 1988. Hugo GARCÍA: "Historia de un mito político. El peligro comunista en el discurso de las derechas españolas (1918-1936)" en Historia Social, n 51, 2005. Serge WOLIKOW: "La creación de la Komintern y la onda expansiva de la revolución en Europa: interacciones y desfases", en Juan ANDRADE y Fernando HERNÁNDEZ SÁNCHEZ (Eds.): 1917. La Revolución rusa cien años después. Madrid, Akal, 2017. Sebastiaan FABER: "Es la hora de la claridad dogmática". El impacto de la revolución rusa en la cultura política española" en Juan ANDRADE y Fernando HERNÁNDEZ SÁNCHEZ (Eds.): 1917. La Revolución rusa cien años después. Madrid, Akal, 2017. Francisco ERICE: "El impacto de la revolución rusa en el movimiento obrero español: el surgimiento del PCE" en Juan ANDRADE y Fernando HERNÁNDEZ SÁNCHEZ (Eds.): 1917. La Revolución rusa cien años después. Madrid, Akal, 2017. José Luis MARTíN RAMOS: "Del fin del ciclo de Octubre al Frente Popular" en Juan ANDRADE y Fernando HERNÁNDEZ SÁNCHEZ (Eds.): 1917. La Revolución rusa cien años después. Madrid, Akal, 2017. Xosé M. NÚÑEZ SEIXAS: Camarada Invierno. Experiencia y memoria de la División Azul (1941-1945). Barcelona, Crítica, 2016. Juan AVILÉS FARRÉ: "El impacto de la Revolución rusa en España, 1917-1922" en Javier TUSELL, Juan AVILÉS y Rosa PARDO (Eds.): La política exterior de España en el siglo XX. Madrid, Biblioteca Nueva, 2000. Juan AVILÉS FARRÉ: La fe que vino de Rusia. La revolución bolchevique y los españoles (1917-1931). Madrid, Biblioteca Nueva-UNED, 1999.
} 
con que sueña." Es decir, es la primera vez que se utiliza este término para describir la realidad española, entendiendo por checa un espacio de represión liderado por un jefe al que no se puede contradecir y al que solo hay que obedecer. Además, con el uso del término "mandarín" se reflejó una creencia extendida entre las derechas, que el comunismo era procedente de Asia no de la "civilizada" Europa.

Posteriormente, el término checa fue utilizado como referente comparativo del uso de la fuerza y los métodos de coerción por parte del Estado. Un ejemplo se encontró ante los sucesos de Casas Viejas, donde los colectivos conservadores compararon la actuación de las fuerzas del orden público español frente a las soviéticas, insinuando que las españolas imitaban a la Cheká rusa (a la que catalogaron como "verdadera aristocracia de clase"). La última referencia para España en relación con la Cheká que ha encontrado, fue un mes antes del golpe de estado del 17 de julio de 1936, el 27 de junio de ese mismo año. En relación al debate sobre la ratificación y ampliación del decreto de amnistía en el Congreso para los presos políticos (generalmente de izquierdas) del bienio radical-cedista. En una de sus intervenciones, el diputado de la CEDA Juan Bautista Guerra García, contrario al decreto, defiende que en los centros de detención se producen casos de maltrato a los detenidos (de derechas, ya que hay que tener en cuenta que la Falange había sido ilegalizada) y "actuaciones que han pasado ya a la categoría de la Cheka", afirmación que produjo diversas protestas en la bancada del Frente Popular. Por tanto, el diputado Juan Bautista se opuso a la liberación de presos políticos de izquierdas y se quejó del trato que recibieron los detenidos de derechas durante la primavera de 1936 en las comisarías y cárceles estatales, acusando así de forma directa al Gobierno de permitir semejante comportamientos, y al compararlo con la Cheká rusa, criticarlos ideológicamente al ser ambos gobiernos de izquierdas, sin tener en cuenta las diferencias existentes entre los dos sistemas. Por ello, el Ministro de Justicia, Manuel Blasco Garzón, le instó a poner exponer ejemplos, que finalmente no expuso, pero todo parece indicar, que aludía a la supuesta situación de persecución de la derecha por el gobierno del Frente Popular. No hay que olvidar que para estas fechas, la Falange estaba ilegalizada. ${ }^{35} \mathrm{En}$ todo caso, de las cuatro referencias, dos de ellas aludieron a que en España, las fuerzas del orden, durante los mandatos de la izquierda, se convierten en una especie de policía política que incumple

\footnotetext{
${ }^{35}$ ABC-Madrid, 27-12-32, p. 36, 17-01-33, p. 31, 15-03-33, p. 30, 27-06-1936, pp. 23-25.
} 
la ley para favorecerles políticamente, y reprimir a los colectivos políticos que no piensan como ellos. Nada más lejos de la realidad, como bien ha estudiado el historiador Eduardo González Calleja. ${ }^{36}$

Durante la guerra civil, el término checa hacía referencia a los tribunales que se crearon dentro de los comités y al espacio, entendido éste como centro de detención y tortura, antesala de la muerte. Literatos falangistas como Agustín de Foxá o Tomás Borrás emplearon, en sus obras referentes al Madrid en guerra, el término checa en este sentido. ${ }^{37}$

La primera vez que este término fue utilizado en la guerra por la prensa franquista fue el 17 de septiembre de 1936 en el $A B C$ de Sevilla. En este periódico apareció una noticia que hizo alusión a la existencia de una checa en Madrid, más concretamente al Radio Norte. A través del relato de una mujer evadida de la capital, Carmen Fernández de Lara, ${ }^{38}$ el periódico enumera los horrores vividos por esta mujer en la ciudad de Madrid. Lo más importante de esta noticia es que aparece por primera vez la palabra checa ligada a los comunistas, de los que dice la entrevistada que "matan, roban y saquean a su voluntad." Además, añade que "todos los días aparecen en la Moncloa y en la Casa de Campo unas cuarenta o cincuenta personas asesinadas por las milicias. Pero estas víctimas no son sólo gentes de derecha, sino también de izquierda, y hasta gentes sin filiación política alguna." ${ }^{39}$ En relación a la primera parte, las características de la violencia, ésta fue llevada a cabo por los comunistas, auténticos dueños de la ciudad. Esta afirmación solo reforzaría el argumento legitimador del golpe de que se iba a producir una incipiente revolución bolchevique en España. Por ello, se relaciona con el ejercicio de violencia a los comunistas, en general, y a los del Radio Norte, en particular. En la segunda parte se alude a la situación anárquica que se vivió en la capital en el verano otoño de 1936 y a la violencia incontrolada que en ella se produjo. Ambos fueron argumentos recurrentes de la propaganda franquista, más concretamente de los relatos de los evadidos de la retaguardia

\footnotetext{
${ }^{36}$ Eduardo GONZÁLEZ CALLEJA: En nombre de la autoridad. La defensa del orden público durante la Segunda República española (1931-1936). Granada, Comares, 2014.

37 Agustín de FOXÁ: Madrid de Corte a Checa. Salamanca, Jerarquía, 1938; Tomás BORRÁS, checas de Madrid. Edición crítica de Álvaro LÓPEZ FERNÁNDEZ y Emilio PERAL VEGA. Madrid, Escolar y Mayo, 2016.

${ }^{38}$ Mujer de clara filiación antirrepublicana, coautora junto a su madre, Carmen Velacoracho de Lara, de la revista Aspiraciones. En esta revista se publicaron artículos que defendieron la sanjurjada, además de textos de claro contenido antisemita.

39 Periódico ABC, jueves 17 del IX de 1936. Edición de Sevilla, pp. 5-6.
} 
republicana. Otro dato interesante de esta noticia es que apareció el término checa en la prensa franquista el mes que la URSS cambio su postura con respecto a la guerra civil española y decidió ayudar a la Segunda República. Más concretamente, la noticia apareció a un día de la firma de acuerdo que dio lugar a las Brigadas Internacionales.

\section{GUERRA Y REVOLUCIÓN EN ESPAÑA. LOS COMITÉS REVOLUCIONARIOS Y LA ORGANIZACIÓN DE LA RETAGUARDIA}

El 17 de julio de 1936 un grupo de militares se sublevaron en el Protectorado marroquí. En los días sucesivos se fue extendiendo a guarniciones peninsulares con el apoyo de civiles y cuerpos de seguridad afines a los intereses de los militares insurrectos. El golpe no triunfó en todo el territorio estatal gracias a los esfuerzos de la ciudadanía en armas (no toda la ciudadanía, sino aquellos colectivos obreros, de izquierdas o simplemente, simpatizantes de la República) y sectores afines al Gobierno del personal del ejército y los cuerpos de seguridad del Estado. En ese proceso de derrota de los golpistas el Estado perdió el monopolio de diversas atribuciones, entre las que cabe destacar las relacionadas con la justicia y el orden público. El ejercicio de estas funciones fue asumido por los comités que surgieron a raíz del golpe de Estado como forma improvisada para combatir a los golpistas y sus apoyos civiles. Una situación inesperada que llevó a una gran parte de los colectivos de izquierda a improvisar respuestas que ayudasen a derrotar a los golpistas y que iniciasen un proceso revolucionario. Estos comités surgieron dentro de las sedes de partidos y sindicatos de izquierdas, principalmente obreros (anarquistas, socialistas y comunistas). Por lo tanto, centros de actividad local como los ateneos libertarios, los radios comunistas o los círculos y agrupaciones socialistas y las casas del pueblo, se convirtieron en espacios de poder con capacidad para imponer su voluntad en las áreas donde se implantaron y en lugares próximos a estas. Desde los comités se fueron improvisando respuestas a las situaciones que se dieron a raíz del golpe de estado. Aunque las labores relacionadas con la represión fueron las que tuvieron una mayor transcendencia, estos órganos también intervinieron en la incautación y reparto de víveres y materiales, en la organización y defensa de sus propios espacios y de los colindantes y organizaron cooperativas. ${ }^{40}$ En resumen, los comités, constituidos de forma autónoma e

\footnotetext{
${ }^{40}$ Archivo General e Histórico de la Defensa (AGHD), Sumario 61130, legajo 6109.
} 
improvisada, asumieron una serie de funciones que de cara a la ciudadanía afín se vieron legitimadas. El reparto de alimento y bienes o el ejercicio de una justicia "del pueblo" les hizo tener un gran apoyo popular, lo que a su vez les permitió disputar el espacio al Estado $\mathrm{y}$ al resto de centros con los que compitieron.

Los comités fueron muy heterogéneos entre sí, tanto en personal como en funciones. Cada centro tuvo su propia estructuración y, en función de la misma, diversas funciones. Los comités madrileños se constituyeron a partir de los socios y militantes de organizaciones, en el mayor de los casos, obreras, que ya estaban asentadas en la zona. Nos referimos a centros con un carácter político, como fueron las Agrupaciones Socialistas o los Radios Comunistas, culturales o sociales, como fueron, para ambos casos, los Ateneos Libertarios, los Círculos Socialistas y las Casas del Pueblo. ${ }^{41}$ Sin embargo, estos espacios no fueron los únicos que se sumaron al proceso revolucionario. Miembros de estas organizaciones presentes en pequeñas instituciones locales, distantes del poder central, como fueron los ayuntamientos de pequeños pueblos cercanos a la capital, crearon comités en las antiguas sedes del poder estatal con representación de todas las fuerzas políticas de izquierdas presentes en los pueblos. Un ejemplo fue el comité que se constituyó en la Villa de Vallecas, uniendo fuerzas todos los partidos y sindicatos de izquierdas presentes en el pueblo. ${ }^{42}$

Al compartir sede y socios el comité revolucionario y el centro político o social determinado (una casa del pueblo, un ateneo o un radio comunista) las fuentes franquistas ligaron el destino del segundo al primero. Todo fue violencia para el franquismo. De esta manera se castigó a todas aquellas personas que tuvieron una activa militancia política, ya fuese en cuestiones sociales, culturales o políticas, muy alejada de la violencia de las personas que compusieron los comités. Aunque todas las personas que formaron parte de los comités fueron socios de estos centros, no todos los socios formaron parte de los comités, y, por tanto, no ejercieron violencia directa sobre los detenidos. Fueron colaboradores necesarios al conocer lo que allí estaba pasando y no interceder sobre el porvenir de los detenidos.

\footnotetext{
${ }^{41}$ Centro Documental de la Memoria Histórica (CDMH), PS-Madrid, Caja 1019, Expediente 3.

${ }^{42}$ AGHD, Fondo Madrid, Sumario 61130, legajo 6109.
} 
Los diversos Gabinetes que se sucedieron a lo largo del verano-otoño de 1936 mantuvieron una discreta presencia en la calle, ahora en manos de los comités. El Estado no desapareció ni se colapsó, sino que luchó por recuperar su espacio en la escena pública. En general, los miembros de los Gobiernos que se formaron tras el golpe de estado rechazaron la violencia protagonizada por los micropoderes revolucionarios. Giral y su gabinete llevaron a cabo medidas para controlar la violencia revolucionaria y someterla a la voluntad estatal para ponerla freno. ${ }^{43}$ Sin embargo, el Gobierno nunca buscó un enfrentamiento directo con estos centros, ya que dependió del apoyo de los partidos políticos y sindicatos a los que pertenecieron los integrantes de los comités para derrotar a los sublevados. A su vez, estos micropoderes nunca contaron con el poder suficiente para enfrentarse abiertamente al Estado y ocupar su lugar.

Dentro de las medidas del primer Gobierno de la República en guerra se contaron una gran cantidad de leyes destinadas a frenar la justicia revolucionaria. Por ejemplo, prohibiciones a la hora de portar armas de diverso calibre en la retaguardia, circulación de vehículos a ciertas horas de la noche o la prohibición de intervenir en registros y detenciones sin autorización para ello. Las leyes también estuvieron destinadas para proteger a la población potencialmente susceptible de ser detenida o de sufrir un registro. ${ }^{44}$ Sin embargo, se sabe que estas medidas fueron escasamente respetadas por los miembros de los comités. Junto con estas medidas, el Gobierno llevó a cabo una campaña de desprestigio de los comités y su labor represiva a través de la radio y la prensa escrita. Recurriendo a expresiones como "incontrolados," el Estado pretendió, primero eliminar cualquier atisbo de sospecha de colaboración con estos poderes locales, ${ }^{45}$ al tiempo que marcaba distancias. Así, el Estado no se veía inmerso en estas actividades ni se responsabilizaba de las mismas. También, con el uso de este adjetivo se pretendió hacer ver la ilegitimidad de estos centros para ejercer semejantes funciones, ya que el Estado era el único a quien correspondería desempeñarlas. Se culpaba y responsabilizaba así a otros

\footnotetext{
43 Javier CERVERA GIL: Contra el enemigo de la República desde la ley. Detener, juzgar y encarcelar en guerra. Madrid, Biblioteca Nueva, 2015. pp. 40-77.

${ }^{44}$ Ibídem, pp. 45-70.

45 Javier RODRIGO: Hasta la raíz. Violencia durante la guerra civil y la dictadura franquista. Madrid, Alianza Editorial, 2008. p 26; José Luis LEDESMA “Una retaguardia al rojo. Las violencias en la zona republicana” en Francisco ESPINOSA MAESTRE (Ed.): Violencia Roja y Azul. España, 1936-1950. Barcelona, Crítica, 2010. pp. 192-198.
} 
colectivos, los comités, de llevar a cabo semejante labor y de desfavorecer a la causa republicana, ofreciendo una mala imagen a las potencias exteriores. El gobierno responsabilizó principalmente de la dirección de estos centros a anarquistas, algo totalmente lógico para el gabinete, dado que fue la mayor fuerza de la retaguardia republicana que no estuvo integrada en el Frente Popular, base del Gobierno. ${ }^{46}$ Además, incontrolados porque no eran fuerzas sometidas a la voluntad del Estado, actuaban de forma autónoma al mismo. Sin embargo, la actuación de estos comités revolucionarios estuvo pautada desde dentro, por lo que nunca se consideraron a ellos mismo como incontrolados y su actuación represiva como indiscriminada.

Con el objetivo de intentar acabar con el protagonismo de estos centros, el Gobierno llevó a cabo distintas medidas. Por un lado, pusieron en marcha un proceso reformista, que pretendió adaptar la administración a la nueva situación, generando leyes y decretos para frenar a los comités. Y, por otro lado, crearon el Comité Provincial de Investigación Pública a iniciativa de Manuel Muñoz, director de la Dirección General de Seguridad (DGS), el 4 de agosto de 1936. En la formación de este centro participaron todas las fuerzas políticas y sindicales defensoras de la República (CNT, FAI, FIJL, PS, PSOE, UGT, PCE, JSU, IR y $U R^{47}$ ). En un principio, Manuel Muñoz quiso que fuese un centro donde se realizasen registros y detenciones, trasladando a los sospechosos a la DGS. No obstante, las fuerzas revolucionarias presentes en la reunión constitutiva solicitaron poder juzgar a los detenidos. Manuel Muñoz aceptó en un ejercicio de cesión para que las fuerzas político sindicales allí reunidas no le retirasen el apoyo. Considerando que poco a poco podría someterlos una vez estuviesen dentro del sistema estatal. Sin embargo, no fue así. El CPIP se convirtió en un centro de referencia dentro de los órganos revolucionarios que lo compusieron, enviando a sus brigadistas a servir en este centro, realizando todo tipo de labores judiciales y de orden público sin ningún control por parte del Gobierno. Por lo tanto, esta medida en tanto en cuanto fue creada para controlar a los comités revolucionarios y sus brigadillas

\footnotetext{
${ }^{46}$ Maria THOMAS: La fe y la furia... p. 100.

${ }^{47}$ Confederación Nacional de Trabajadores (CNT), Federación Anarquista Ibérica (FAl), Federación Ibérica de Juventudes Libertarias (FIJL), Partido Sindicalista (PS), Partido Socialista Obrero Español (PSOE), Unión General de Trabajadores (UGT), Partido Comunista Español (PCE), Juventudes Socialistas Unificadas (JSU) Izquierda Republicana (IR) y Unión Republicana (UR).
} 
fracasó. ${ }^{48}$ Ante la constatación del fracaso del CPIP, se intentó de nuevo incorporar a los miembros de los comités a instancias estatales. ${ }^{49}$ Se constituyeron así las Milicias de Vigilancia de Retaguardia, MVR, pero en este caso, en vez de atraer a las cúpulas directivas de los sindicatos y partidos políticos que lucharon dentro de la retaguardia republicana, se intentó con las MVR atraer a las bases, incorporándolas como milicianos para poder controlarlos. Sin embargo, se volvió a fracasar en este intento. Tanto las Milicias como el Comité fueron dos instituciones que se crearon con la intención de incorporar elementos revolucionarios al Estado para hacer ver a la población que apoyó las iniciativas revolucionarias de los comités locales, que el Gobierno había cambiado. Que había incorporado elementos revolucionarios a su corpus doctrinal. Sin olvidar que las exigencias de la guerra y la necesidad de una retaguardia preparada para una guerra larga y total (concepción dada desde octubre-noviembre) también influyeron en el control de la violencia y la desaparición de los comités.

\section{VALEDORES DE LA “JUSTICIA DEL PUEBLO”. LOS COMITÉS Y LA VIOLENCIA REVOLUCIONARIA}

Este proceso de justicia paralela o justicia "por consenso" que llevaron a cabo los integrantes de estos centros, se caracterizó por la búsqueda de la inmediatez en el veredicto y el cumplimiento de la sentencia. ${ }^{50}$ Todo parece indicar, que no se produjeron juicios dentro de estos locales, sino que detenían a los sospechosos, sobre los cuales había una denuncia previa o era conocida su actitud derechista por los miembros de estos centros. Otra forma de obtener información sobre los sospechosos, fue acudir a fuentes de información, como los porteros, quienes conocían las afinidades políticas de sus vecinos. Los responsables de estos centros debatían sobre qué resolución tomar frente al detenido. Podía ser considerado culpable y ser ejecutado o trasladado a dependencias oficiales (cárceles) o quedar en libertad. ${ }^{51}$

\footnotetext{
${ }^{48}$ Cuadrillas de milicianos especializados en la realización de registros, detenciones y ejecuciones. Un ejemplo fue la brigada de los "Cinco Diablos" que actuó bajo las órdenes del comité socialista de la Agrupación encuadrada en la Casa del Pueblo del Puente de Vallecas, Madrid.

49 Julius RUIZ: El terror rojo. Madrid, 1936. Barcelona, Espasa, 2012. pp. 124-126 y pp. 209-212.

50 Javier CERVERA GIL: Contra el enemigo... p. 124-128.

${ }^{51}$ Paul PRESTON: El Holocausto español... p. 375.
} 
En estos procesos de detención, traslado, y posible ejecución, intervinieron diversos agentes, no solo aquellas personas que formaron parte de las brigadillas. Las personas que compusieron estas brigadillas, pudieron recurrir a la ayuda o asistencia de vecinos de la zona, que se encontraban en las patrullas y controles. No obstante, no todas las personas que estuvieron en controles o patrullas, o pertenecieron a estas organizaciones fueron responsables de la violencia llevada a cabo por el centro o culpables de cometer algún tipo de delito (como lo juzgará el régimen franquista).

A lo largo de los cuarenta años de dictadura, la violencia que aconteció en la retaguardia republicana fue objeto recurrente de la literatura afín al franquismo como forma de legitimación del nuevo régimen y de su justicia. ${ }^{52}$ Ya en la guerra civil empezaron a aparecer relatos de vida y novelas ambientadas en la retaguardia republicana donde se empezó a definir las características de la violencia. Características que el régimen mantuvo vivas a lo largo de sus cuatro décadas de vida, aunque carecieran de fundamento empírico. Los objetivos fueron varios y muy diversos. Durante la guerra, por ejemplo, se persiguió desde la descalificación del enemigo haciendo a todos culpables, hasta la generación de un imaginario colectivo plagado de horrores que fomentase la lucha contra ese enemigo, y eliminase cualquier posibilidad de ayuda exterior a la Segunda República.

En lo que atañe a la violencia en sí, estos relatos trataron el tema como una "combinación de propaganda, martirologios y silencios, de conmemoración para unos y miedo para otros y mitos para casi todos." 53 Por lo tanto, se ofreció una "visión impresionista" de los acontecimientos violentos, en tanto que no recurrió a la sistematización y crítica de las fuentes, sino que se valió de "la propaganda, los adjetivos y las exclamaciones." 54 La imagen que estos relatos quisieron dar sobre la violencia en la retaguardia republicana fue la de un "terror sistemático o científico" de inspiración bolchevique. El mejor ejemplo, según el historiador Hugo García, fue que "no hay relato ambientado en Madrid que no incluya su checa, normalmente descrita como un sótano

\footnotetext{
${ }^{52}$ Hugo GARCÍA: “Relatos para una guerra..." p. 145.

53 José Luis LEDESMA: "Del pasado oculto a un pasado omnipresente: Las violencias en la Guerra Civil y la historiografía reciente", Jerónimo Zurita. Revista de Historia, 84 (2009). p. 165.

54 José Luis LEDESMA: "El 1936 más opaco: las violencias en la zona republicana durante la Guerra Civil y sus narrativas", en Historia Social, 58 (2007). p. 152.
} 
tétrico y siniestro que sirve de cámara de tortura a milicianos sucios y malvados". ${ }^{55}$ Todo ello, en medio de un ambiente de caos, anarquía y destrucción. ${ }^{56}$

La violencia que sucedió al golpe de estado del 17 de julio de 1936 no persiguió los mismos fines ni tuvo las mismas motivaciones que la violencia acontecida en los años de la Segunda República. En palabras de José Luis Ledesma, "las luchas y la violencia de los años de la Segunda República respondieron a una "aguda conflictividad multisectorial" vinculada a los enfrentamientos políticos-ideológicos, sociales, laborales y simbólicos" ${ }^{57}$

Sin embargo, la mayor parte de los historiadores de la violencia en zona republicana afirman que "los odios, venganzas y pesadillas justicieras que se extendieron a partir del 17 de julio eran tan intensos que por fuerza venían de atrás" ${ }^{58}$ Esto no quiere decir que la violencia de preguerra o los discursos políticos cargados de referencias belicistas y de llamamientos a la lucha estuvieran anunciando la llegada de una guerra civil o de la violencia. ${ }^{59}$ Es más, los niveles de violencia acontecidos tras el golpe de estado fueron fruto de los militares insurrectos, quienes favorecieron y sancionaron el uso de la violencia como

\footnotetext{
${ }^{55}$ Hugo GARCÍA: "Relatos para una guerra..." p. 168.

${ }^{56}$ José Luis LEDESMA VERA: “Qué violencia para qué retaguardia, o la República en guerra de 1936", Ayer, 76, 4 (2009). p. 96.

${ }^{57}$ José Luis LEDESMA: "Del pasado oculto..." p. 173. La violencia que registró la Segunda República no fue fruto del sistema político, sino que viene de lejos. A lo largo de las tres primeras décadas del siglo XX el país, en palabras de José Luis Ledesma, experimentó "una creciente conflictividad y una imparable crisis de legitimidad del Estado liberal,(...) la reactualización de un violento pretorianismo en el Ejército español desde principios de siglo; la persistencia y reactualización de subculturas políticas con componentes excluyentes; o la existencia de una doble tradición sindical con dos grandes sindicatos que se disputaban radicalmente el mercado de trabajo. (...) todo ello se traducía en la ausencia de una verdadera tradición de respeto a las normas y mecanismos del sistema político parlamentario, y en una aceptación generalizada en el uso de la violencia como instrumento de competencia política, de acceso al control del Estado y de lucha por la configuración del orden social." José Luis LEDESMA: “¿Cuchillos afilados? De violencias, guerra civil y culturas bélicas en la España del primer siglo XX”, en Jordi Canal, Eduardo González Calleja (eds.), Guerras civiles. Una clave para entender la Europa de los siglos XIX y XX, Casa de Velázquez, Madrid, 2012. pp. 9192.
}

58 José Luis LEDESMA: "sobre revoluciones, violencias y la España republicana en guerra," en Francisco MORENTE (Ed.): España en la crisis europea de entreguerras. República, fascismo y guerra civil. Madrid, La Catarata, 2011. p. 114. En palabras de Enzo Traverso, en una guerra civil "La rutina está rota. Lo que normalmente estaba prohibido se encuentra ahora permitido. En la guerra civil el homicidio pierde su utilidad y se convierte en la inmolación del enemigo y el sacrificio de los combatientes. El odio pierde su carácter abstracto, deja de ser un sentimiento que nutre determinadas opciones políticas y se vuelve una pulsión que se traduce en actos. Este paso es posible por la suspensión del derecho y el cuestionamiento del monopolio estatal de la violencia. Las obligaciones sociales y culturales que forjan nuestras normas de conducta estallan. El autocontrol de las pulsiones que impide al individuo civilizado caer en el placer de la agresión desaparece". Enzo TRAVERSO: A sangre y fuego: de la guerra civil europea (1914-1945). Valencia, Universidad de Valencia, 2009. p. 77.

59 José Luis LEDESMA “Una retaguardia al rojo..." p. 157. 
forma de resolución de los conflictos sociales, abocaron a que las armas invadiesen las calles y, con el golpe, rompieron las reglas y el marco legal republicano sobre la resolución de conflictos. ${ }^{60}$ El golpe de estado, al favorecer la aparición de esa violencia, abrió un proceso de deshumanización del adversario, convertido ahora en enemigo, que tuvo como consecuencia "la aniquilación física sin precedentes al compás de la guerra total". ${ }^{61}$ Por lo tanto, las violencias que tuvieron lugar tras el golpe de estado nunca se hubiesen producido "sin la apertura de un contexto de radical enfrentamiento armado" como fue la guerra civil española. ${ }^{62}$ En definitiva, "la violencia que se produjo hasta la primera mitad de julio fue un arma retórica y real dentro, casi de forma exclusiva, de los sectores más comprometidos de las luchas socio-políticas, y que con la guerra pasó a ser un instrumento al alcance de todos". 63

Además, la violencia que se produjo en la retaguardia republicana se insertó en un proceso revolucionario abierto por el golpe de estado, dentro de una guerra civil. Escenarios ambos cambiantes en el imaginario y en función de los acontecimientos. Es más, en relación a la revolución no hubo una concepción unitaria entre todas las fuerzas partidarias de la misma, al igual que fue un fenómeno inusual, inédito y nuevo que se fue improvisando en relación al devenir de los acontecimientos hasta que fue integrada y controlada por el Estado. ${ }^{64}$ Por lo tanto, no hubo un proyecto revolucionario previo al golpe como alegaron los sublevados como forma de legitimar su insurrección. ${ }^{65}$ En el caso del golpe de estado fue concebido como una operación contra el gobierno de la Segunda República que quedaría resuelto en cuestión de días, a lo sumo semanas, "una rebelión militar que se sirvió de la violencia para paralizar y ahogar en sangre si era necesario toda

\footnotetext{
60 José Luis LEDESMA: “Del pasado oculto...” p. 172.

${ }^{61}$ Gutmaro GÓMEZ BRAVO y Alejandro PÉREZ-OLIVARES: "Las lógicas de la violencia en la guerra civil. Balance y perspectivas historiográficas", Estudio Historia Contemporánea 32, Salamanca, Universidad de Salamanca, 2014. p. 254.

62 José Luis LEDESMA VERA: “Qué violencia...” p. 89.

63 José Luis LEDESMA: "sobre revoluciones..." p. 114.

64 José Luis LEDESMA: “"La santa ira popular» del 36: la violencia en guerra civil y revolución, entre cultura y política," en Javier MUÑOZ SORO, José Luis LEDESMA, Javier RODRIGO (coords.): Culturas y políticas de la violencia. España siglo XX, Siete Mares, Madrid, 2005. p. 161.

65 Javier CERVERA GIL: Madrid en guerra... p. 59.
} 
resistencia, y que provocó entre sus oponentes una respuesta no menos feroz". ${ }^{66}$ Una violencia que quiso impedir el asentamiento de la sublevación o su derrota. A finales de julio esta concepción cambió, abriéndose un periodo de conflicto improvisado a través de la formación de columnas que produjo la extensión de la violencia, que ya no buscaba solo paralizar al enemigo, sino que abrió un periodo de "limpieza política." Otorgándole a la violencia cualidades sanadoras de la sociedad, "considerada por muchos como un camino necesario". 67

La estabilización de los frentes en octubre de 1936 trajo consigo la concepción de que el conflicto sería de larga duración. También fue cuando la violencia empezó a ser controlada por el Estado republicano, en el caso de su retaguardia, y a "enfriarse," operando para ello la necesidad de control para ganar el conflicto y la búsqueda de apoyos en el exterior, en el nuevo marco de guerra total. ${ }^{68}$ Como se puede ver, todos estos cambios en la concepción de la guerra y la revolución tienen su materialización en la violencia. Una violencia que necesariamente no tuvo por qué ir ligada a ninguno de los dos procesos abiertos por el golpe de estado del 17 de julio de $1936 .^{69}$ Sin embargo, Enzo Traverso, siguiendo las argumentaciones de Mayer, definió la revolución como: "una ruptura creadora de un nuevo orden que, sostenido por masas activas, surge de un vacío de poder en el apogeo de una crisis social y política (...) tal ruptura implica el uso de la fuerza. No hay revolución sin violencia." Una violencia ligada a otro fenómeno indisoluble de la revolución, la contrarrevolución, ya que una produce la otra. ${ }^{70}$

Otra de las características es que la violencia y sus formas fueron evolucionando a la par que lo hizo el conflicto. No fue una violencia sistemática y organizada como fue la protagonizada por las fuerzas sublevadas, y fue limitada en el tiempo y en intensidad. ${ }^{71} \mathrm{~A}$

\footnotetext{
${ }^{66}$ José Luis LEDESMA VERA: “Qué violencia...” p. 94.

${ }^{67}$ Javier MUÑOZ SORO, José Luis LEDESMA, Javier RODRIGO (coords.): "Presentación. La cultura de la fuerza o la fuerza de la cultura," en Javier MUÑOZ SORO, José Luis LEDESMA, Javier RODRIGO (coords.): Culturas y políticas de la violencia. España siglo XX, Siete Mares, Madrid, 2005. p. 11.

${ }^{68}$ José Luis LEDESMA: “Del pasado oculto..." p. 175.

69 José Luis LEDESMA VERA: “Qué violencia..." p. 98.

${ }^{70}$ Enzo TRAVERSO: La historia como campo de batalla. Interpretar las violencias del siglo XX. Buenos Aires, Fondo de Cultura Económica, 2012. pp. 87-89.

${ }^{71}$ El mes donde se produjeron más ejecuciones y asesinatos fue agosto de 1936. En los meses sucesivos iría disminuyendo. Es más, en los seis primeros meses de guerra se agrupa el $97,6 \%$ de las ejecuciones en Madrid de todas las que se produjeron a lo largo de la contienda. Javier CERVERA GIL: Madrid en guerra...
} 
partir de octubre, con la fijación de los frentes y las necesidades propias de una guerra total (que exigió disciplina y orden en las retaguardias), la violencia disminuyó a la par que lo hizo el espacio político y público ocupado por los comités. ${ }^{72}$ Sin embargo, no se puede hablar de organización de la violencia desde arriba en la retaguardia republicana. Un mosaico de micropoderes irrumpió en la escena pública ocupando un espacio dejado por el Estado. Estos micropoderes, en general comités revolucionarios, fueron los principales promotores de la violencia en la retaguardia, no el Gobierno republicano.

Uno de los desencadenantes de la apertura de este proceso de oportunidades y espacios que fue la revolución fue la pérdida súbita de capacidades, funciones y atribuciones del Estado. ${ }^{73}$ Aunque la administración estatal perdió el monopolio en el ejercicio de algunas de sus funciones, como las represivas o las de orden público, no llegó a colapsarse ni desapareció. Se convirtió en un actor más en la lucha por recuperar el poder perdido. Lucha que llevó a cabo contra los nuevos poderes que se lo habían apropiado y que hicieron uso de él sin consentimiento e incluso en contra de los intereses del Gobierno. La apropiación por parte de los comités de las funciones represivas produjo la aparición de formas de actuación colectiva no pautadas por la legalidad, un ejemplo en relación a las labores represivas se dio en las formas de infligir el castigo. ${ }^{74}$ La administración de ese castigo (uno de los principales ámbitos de acción de los comités, no el único) por parte de estos centros fue una forma de desafiar al poder estatal y "una fuente inmediata para obtener, gestionar y conservar esos espacios alternativos de poder". ${ }^{75}$ Aunque la violencia fue llevada a cabo por los comités, fue el golpe de estado, y sus

\footnotetext{
pp. 74-76. Un mínimo de 5.800 personas fueron asesinadas y ejecutadas entre julio y octubre de 1936 . Javier RODRIGO: Hasta la raíz... p. 40.

${ }^{72}$ La estabilización de los frentes trajo consigo la reducción de la violencia y de esos espacios de poder de los comités para ejercerla. José Luis LEDESMA: Los días de... p. 133.

${ }^{73}$ Rafael CRUZ: "Pensar la violencia colectiva europea en perspectiva histórica" en Javier MUÑOZ SORO, José Luis LEDESMA, Javier RODRIGO (coords.): Culturas y políticas de la violencia. España siglo XX, Siete Mares, Madrid, 2005. p. 15.

74 José Luis LEDESMA: "sobre revoluciones..." p. 117.

${ }^{75}$ José Luis LEDESMA “Una retaguardia al rojo..." p. 188.
} 
efectos sobre el Gobierno, el que produjo la liberación de la violencia de forma brusca e incontrolada (para el Estado) por canales no institucionales. ${ }^{76}$

Por su parte, el personal de la administración estatal se dividió en el apoyo y legitimación del uso de este tipo de violencia no controlada por el Estado y ejercida desde abajo. No obstante, se produjo un mayor rechazo que aceptación no solo de las élites políticas, sino incluso dentro de los comités, suponiendo un freno a la violencia ejercida por estos centros, sobre todo estos últimos. ${ }^{77}$ Prueba de ello fueron las constantes iniciativas propuestas por todos los Gobiernos para frenar este tipo de actuaciones represivas. ${ }^{78}$

Por lo tanto, las características que definieron la violencia (no solo física, sino también verbal, material, social o económica) que se produjo en la retaguardia republicana fueron múltiples y muy diversas. Dentro de las primeras acciones que pautaron la actividad relacionadas con la violencia fueron las propias generadas por el golpe de estado, una lógica de contra golpe. En definitiva, una respuesta improvisada para impedir el asentamiento de la sublevación y como forma de contestación a la violencia llevada a cabo por los golpistas. ${ }^{79}$ La violencia acontecida tras el golpe se caracterizó por ser una violencia de guerra, por lo tanto, significaba una ruptura radical respecto a las luchas discursivas, políticas y sociales de los meses previos. Las guerras suponen el escenario ideal de la agresión y la violencia, los viveros principales de las diversas formas de las mismas. Formas que se despliegan a la sombra del conflicto principal y resultan abonadas por la radical invasión de la comunidad por parte de las armas. Y que se nutre de las dinámicas de venganza, del derrumbamiento de los códigos éticos, regulaciones socio-culturales y criterios normativos y de la relativización de la muerte. Además de una nueva forma de hacer la guerra de afán destructivo sin precedentes y una radical e ingente difuminación de las fronteras entre civiles y combatientes. ${ }^{80}$

\footnotetext{
${ }^{76}$ Eduardo GONZÁLEZ CALLEJA: "La dialéctica de las pistolas: la violencia y la fragmentación del poder político durante la Segunda República," en Javier MUÑOZ SORO, José Luis LEDESMA, Javier RODRIGO (coords.): Culturas y políticas de la violencia. España siglo XX, Siete Mares, Madrid, 2005. p. 145.

77 José Luis LEDESMA “Una retaguardia al rojo..." p. 163.

78 Javier CERVERA GIL: Contra el enemigo...; Daniel OVIEDO SILVA y Alejandro PÉREZ-OLIVARES GARCÍA: Madrid, una capital en guerra (1936-1948). Madrid, La Catarata, 2016.

79 José Luis LEDESMA “Una retaguardia al rojo..." p. 158.

${ }^{80}$ José Luis LEDESMA: “"La santa ira popular»..." p. 153. Los miembros de los comités y sus brigadas han sido definidos en algunos trabajos recurriendo al término "especialistas de la violencia" de Charles Tilly. José Luis LEDESMA “Una retaguardia al rojo...” pp. 163-164.
} 


\section{CONCLUSIONES}

A lo largo de este trabajo se ha expuesto el funcionamiento y las lógicas de la violencia que llevaron a cabo la Cheká y los comités revolucionarios populares durante la guerra civil rusa y española respectivamente. El objetivo era exponer ambos organismos para poder llevar a cabo una labor de comparación y valorar la validez del término Cheká en la guerra civil española. Este concepto fue utilizado de forma indiscriminada por el franquismo para definir la actuación violenta llevada a cabo tanto por los comités revolucionarios como las instituciones represivas estatales dentro de la retaguardia republicana a lo largo de toda la contienda. Los locales y sedes del SIM, el DEDIDE, y los comités revolucionarios, fundamentalmente urbanos, fueron considerados checas por el aparato propagandístico y judicial franquista, pero ¿qué tienen en común ambos organismos? $\mathrm{Y}$, sobre todo, ¿es funcional el término checa para definir una realidad tan diversa como la que se vivió en la retaguardia republicana durante los tres años de la contienda, aplicada a espacios y centros tan heterogéneos y dispares entre sí? Estas cuestiones no tienen en el presente una única respuesta dentro de la historiografía. Mientras que hay autores que invitan a la reflexión sobre este término y su uso para la guerra civil española por considerarlo inapropiado, ${ }^{81}$ otros lo asumen conscientes de su complejidad, problematizando sobre su significado o su uso, pero que, de forma general, lo incorporan a sus relatos por considerarlo apropiado para definir los espacios de violencia en la retaguardia republicana. ${ }^{82}$

La influencia y el impacto que tuvo la revolución rusa en España se ha analizado en este trabajo, con el objetivo de valorar la pervivencia de estereotipos, personajes e instituciones, como la Cheká, durante las décadas posteriores a la revolución, para estudiar los significados que le habían otorgado los medios de comunicación y su público a la altura de 1936, para ser conscientes de que significados se le pudieron conceder durante la guerra civil. De esta forma se ha pretendido realizar un estudio de la Cheká y sus significados de cara a dar respuesta a los interrogantes que abren este artículo.

\footnotetext{
${ }^{81}$ Como, por ejemplo, Hugo García, José Luis Ledesma, María Thomas o Julián Vadillo.

${ }^{82}$ Autores como, Javier Cervera Gil, Francisco Espinosa Maestre, Fernando del Rey, Julius Ruiz, Stanley G. Payne o Paul Preston.
} 
Comparando ambos organismos, hay que tener en cuenta, en función de lo expuesto a lo largo de este trabajo, que la institución soviética fue creada y amparada por el Estado con la intención de eliminar a los enemigos del naciente régimen y asentarle en el poder. En el caso español, los centros que se generaron ante el golpe de estado lo hicieron de forma autónoma y muchas veces en contra de los intereses estatales. Es más, estos centros vieron al Estado como un enemigo en las luchas de poder por tomar las calles y representar así la voluntad popular. Por lo tanto, en el modelo ruso hubo desde el principio una coordinación directa entre el Gobierno y la policía política, no así en el caso español, donde los centros surgieron de forma independiente al Estado y sus intereses. El Gobierno ruso pautó e hizo cumplir de forma férrea toda una serie de leyes y normativas que guiaron la vida en la Cheká. Por su parte, los comités españoles se organizaron en función de sus experiencias previas, improvisando respuestas ante una situación inesperada, la perdida de atribuciones por parte del Estado (a consecuencia del golpe de estado y su derrota en el territorio que permaneció leal a la República) y enfrentándose a los decretos que apoyaron los sucesivos gobiernos para hacerlos desaparecer. En resumen, se puede afirmar, en función de su naturaleza, que la Comisión fue una institución del Estado, creada y dotada de contenido por el mismo y subordinada a los intereses del Estado, frente a unos órganos revolucionarios dispares que surgieron para iniciar un fenómeno revolucionario en función de sus preceptos ideológicos y sus experiencias previas. Creados a iniciativa de sus organizaciones políticas o sindicales o por la iniciativa personal de sus miembros. Es decir, la Cheká se corresponde con un modelo revolucionario desde arriba impuesto por el Estado para consolidarse en el poder, mientras que los comités lo hacen desde abajo aprovechando la debilidad del Estado. La Cheká formó parte del Estado, tuvo representantes ante las instituciones, personal administrativo, sede oficial y legitimad, mientras que los comités revolucionarios carecieron por completo de estas atribuciones.

Asimismo, esta naturaleza condicionó las lógicas de la violencia. En el caso bolchevique, la violencia estuvo pautada por los intereses estatales, mientras que, en el caso español, los comités siguieron lógicas revolucionarias e intereses particulares, ligados a su vez a los de la contienda. Se apropiaron de funciones judiciales y las ejercieron en función de sus concepciones de justicia "del pueblo". Por lo tanto, no se consideraron 
asesinos, sino representantes de la voluntad popular. ${ }^{83}$ Los chekistas soviéticos no se enfrentaron a semejantes dilemas de índole moral al ser nombrados agentes oficiales por el régimen y habilitados para el desempeño de funciones de orden público y represivas. En definitiva, el sistema de policía política soviética fue una herramienta estatal mientras que los comités españoles fueron iniciativas autónomas a la voluntad del estado y con intereses enfrentados. Ejerciendo, por lo tanto, una violencia no pautada ni dirigida desde arriba, sino por iniciativa desde abajo. Estas diferencias tienen una implicación en el ejercicio de la violencia, pudiendo hablar de represión, en el caso de la Cheká soviética, y violencia revolucionaria, en el caso de los comités españoles. Asimismo, tuvieron una concepción legal diferente. En el caso de la Comisión, las ejecuciones se hicieron en función de la ley vigente y sancionadas por el Estado, mientras que, en el caso republicano, el Estado dictó leyes para limitar la acción de los comités revolucionarios, sin sancionar el ejercicio de la violencia revolucionaria efectuada por los comités. Es más, se realizaron investigaciones sobre las ejecuciones extrajudiciales, ayudando a los familiares de las víctimas a encontrar a sus seres queridos y se produjeron algunas detenciones, muy escasas. ${ }^{84}$ La multiplicidad de actores en la puesta en práctica de la violencia en la retaguardia republicana hace de este un aspecto complejo. A lo largo de este trabajo hacemos alusión a los comités revolucionarios que suplantaron en las calles el poder del Estado. No entramos en detalle, por considerar que excedería en demasía los objetivos de este artículo, en instituciones emanadas de las instancias gubernamentales como las MVR, el CPIP, los Tribunales Populares, el DEDIDE o el SIM. Por tanto, actos como las matanzas de Paracuellos del Jarama y todo el proceso de organización de las mismas queda fuera de este trabajo, por considerar, por su relevancia y envergadura un estudio monográfico detallado y completo.

Otro factor a tener en cuenta, y que diferencia ambos sistemas es el ideológico. Mientras que la policía política soviética estuvo formada por comunistas, o por lo menos dirigida por estos, en el caso de los comités españoles fueron centros pertenecientes a diferentes corrientes ideológicas de izquierda, desde anarquistas, comunistas, socialistas y republicanas. Esta diferencia influenció en la forma de concebir la violencia revolucionaria y

\footnotetext{
${ }^{83}$ José Luis LEDESMA “Una retaguardia al rojo..." p. 140.

${ }^{84}$ Julius RUIZ: El terror... Para el estudio del hallazgo de cadáveres y los procedimientos policiales republicanos se ha consultado el Archivo General de la Administración (AGA), Fondo Justicia (7). 42.01.44/14740-44/14750.
} 
sus formas de aplicación, así como de dotar de significado a la revolución (pudiendo hablar de procesos revolucionarios para el caso español). ${ }^{85}$ Además, los comités se asentaron en la sede de los centros obreros preexistentes al golpe de estado, dividiendo funciones entre el centro de acogida (ateneos libertarios, radios comunistas o casas del pueblo socialistas) y los comités. Las comisarías de la Cheká fueron eso, comisarias, no centros culturales, ni políticos o sociales, no ayudaron a abrir colegios, ${ }^{86}$ no repartieron alimentos ni ropa o realojaron refugiados de guerra como si hicieron los centros españoles que acogieron a los comités revolucionarios. ${ }^{87}$ La violencia, en el caso español, fue concebida como parte de la revolución no como un todo, como hizo creer el franquismo. Las diferencias entre la organización política o social preexistente y los comités revolucionarios fueron eclipsadas durante la dictadura, y fueron concebidos como un espacio unitario dedicado en exclusiva al robo y la violencia y, por lo tanto, todas las personas que tuvieron relación con estos espacios fueron culpables. ${ }^{88}$

Sin embargo, hubo similitudes entre los comités y la policía política soviética que no se pueden obviar. La constitución de chekas locales durante la guerra civil rusa compartió pautas y procesos con la constitución de los comités revolucionarios, aunque con salvedades, porque las chekas locales fueron creadas a instancia de la Casa Madre, mientras que los comités fueron una reacción popular o política ante un golpe de estado, formada de forma autónoma o por orden del partido o sindicato al que estaba vinculado. La detención de los sospechosos fue otra de las semejanzas que encontramos entre los dos organismos, siendo más frecuentes en horario nocturno, en el domicilio del sospechoso, mediando una denuncia, en los casos en los que ésta se producía, sin un formato previo, el traslado del detenido a la sede, la formación de un proceso, en el caso de los comités no pautados, y llevando a cabo el cumplimiento de las sentencias. La diferencia residió en la legalidad de la actuación de comités y de la Cheká. Por un lado, los comités lo hicieron en función de sus preceptos y en contra de la justicia estatal por considerarla burguesa sin ningún tipo de procedimiento pautado. Por otro lado, la Cheká gozó de un amplio margen de actuación al no poseer una reglamentación interna minuciosa, pero siempre en

\footnotetext{
${ }^{85}$ AGHD, Sumario 15430, legajo 2817; Sumario 45413, caja 999, número 7.

${ }^{86}$ CDMH, PS-Madrid, Caja 452, Expediente 144.

${ }^{87}$ AGHD, Sumario 49380, caja 2001, número 5.

${ }^{88}$ Francisco SEVILLANO: Rojos. La representación del enemigo en la guerra civil. Madrid, Alianza, 2007.
} 
representación de la voluntad del Estado y como forma de defensa ante sus enemigos, reales o imaginados. El contexto de guerra civil en ambos casos hace aumentar las similitudes en los tiempos de los "procesos" desde la denuncia hasta el veredicto tomado por los tribunales o los miembros de los comités. Dada las necesidades y el rápido devenir de los acontecimientos, la celeridad fue una característica que impero en ambos modelos.

Vistas las amplias diferencias que separaron ambos modelos represivos cabría preguntarse el porqué del empleo de este término para definir a los comités españoles. Como se ha podido ver a través del análisis de la prensa, el término resultó familiar para los españoles e identificaba una experiencia revolucionaria de índole comunista a la violencia masiva e incluso despiadada. Ante la aparición de los comités españoles tras el golpe de estado, los sublevados vieron una oportunidad de ligar lo acontecido en zonas como Madrid o Barcelona a la idea de revolución soviética y, por tanto, a la Cheká. Una forma de generar miedos en las potencias democráticas y de desprestigiar a la República, arrinconándola, internacionalmente hablando. Pero también, cumplió una función a nivel nacional, simplificar al enemigo y deshumanizarlo, ligarlo a experiencias e injerencias externas enfrentadas a la "idea de España" promovida por los golpistas. ${ }^{89}$ Asimismo, el empleo del término cheká ocultó la gran heterogeneidad de los comités españoles, que no solo fueron diferentes en función de la ideología de sus miembros (anarquismo, socialismo y comunismo), sino también a la diferente experiencia previa de sus miembros. De esta forma, por ejemplo, encontramos comités anarquistas muy dispares entre sí. Pero no solo sirvió para ocultar esa gran heterogeneidad tipológica de centros, sino que también difuminó las barreras entre los miembros de los comités (responsables de ejercer la violencia revolucionaria) y el personal de los centros que los acogieron. Por lo tanto, y volviendo al ejemplo anarquista, los ateneos que acogieron a los comités de defensa encargados de ejercer la violencia revolucionaria, fueron calificados como "checa" y todos sus miembros, independientemente de si pertenecieron al comité o al ateneo, fueron calificados de chequistas. Todo ello operó en la propaganda franquista para generar la idea de enemigo. Incluso, esta propaganda calificó de "checas" a los comités revolucionarios y a lo que posteriormente fue el Servicio de Información Militar (SIM) eliminando de esta forma, las múltiples diferencias existentes entre estos dos modelos de centros y su forma de

\footnotetext{
${ }^{89}$ Zira BOX: España, año cero: la construcción simbólica del franquismo. Madrid, Alianza, 2010.
} 
ejercer la violencia. Otro aspecto a tener en cuenta, relacionado con el anterior, es el factor temporal. No fue lo mismo el verano revolucionario de 1936, con los comités revolucionarios, que el SIM de 1937 y su posterior evolución a lo largo de la guerra. Al igual que no fue lo mismo la situación en Madrid, Barcelona, Valencia o el País Vasco.

Por lo tanto, concluimos este trabajo afirmando que el término "checas" usado para definir a los comités revolucionarios del verano otoño de 1936 en Madrid no es válido para recoger la heterogeneidad de estos centros ni su disparidad, tanto con el espacio receptor (ateneo, círculo, casa del pueblo o radio) como con el comité encargado de asumir las funciones relacionadas con la justicia revolucionaria. Es decir, los comités revolucionarios nacidos de partidos y sindicatos, mayoritariamente obreros, fueron y se concibieron como comités, no como checas. Este aspecto es importante, al destacar que en las fuentes consultadas entre julio de 1936 y abril de 1939 para la retaguardia republicana el concepto checa no aparece para definir la actuación que llevaron a cabo los comités ni como forma de autodenominarse. Siempre aparecen referenciados como comités. También habría que preguntarse por qué el concepto checa solo se ha utilizado para las ciudades y no para los pueblos donde se mantuvo el término con el que se definieron, comité. Solo se ha encontrado el concepto que hace alusión a la Comisión rusa en documentos internos, como en el caso de la Junta de Defensa, como forma de descredito hacia el rival político o como forma de calificar las acciones violentas del contrario. En cambio, a partir de septiembre de 1936, el concepto que alude a la primera policía política soviética aparece en la prensa franquista (justo cuando coinciden en el tiempo la ayuda soviética y la llegada de las Brigadas Internacionales), en los relatos autobiográficos y novelados a partir de 1937 (cuando los comités ya no estaban operativos, en general), o en los consejos de guerra franquistas de 1939. Sin embargo, esto no quiere decir, por supuesto, que se niegue la presencia de asesores soviéticos en la retaguardia republicana o menospreciar la violencia que llevaron a cabo estos centros.

Este estudio tenía como objetivo poner en cuestión el concepto checa para la guerra civil española, más concretamente para definir a los comités revolucionarios madrileños que surgieron en el verano otoño de 1936. Como se ha podido leer a lo largo del trabajo, no es un debate cerrado, y lo que se ha pretendido es ampliar este debate que, mucho menos, cerramos con este artículo. Es más, aún queda mucho por hacer en relación al estudio de los centros creados por Estado para frenar la revolución, como el CPIP, las MVR, el 
DEDIDE o el SIM. También queda por hacer el estudio del impacto del concepto de la policía política soviética en la prensa y escritos durante los años veinte y treinta del siglo pasado, analizar el uso dado a este concepto por el franquismo y la intencionalidad del mismo, el lugar que ocupaba esta institución en el imaginario colectivo obrero, como modelo a imitar, o bien como modelo a evitar, además, de un estudio integran de los comités revolucionarios madrileños.

\section{FUENTES:}

- Hemeroteca $A B C$

- Archivo General de la Administración (AGA)

- Archivo General e Histórico de la Defensa (AGHD)

- Centro Documental de la Memoria Histórica (CDMH)

\section{BIBLIOGRAFÍA:}

- Mikel AIZPURU MURUA, "Ciudadanía e Inmigración. Los exiliados rusos en España (1914-1936)" en Ayer, nº 78 (2), 2010.

- Juan AVILÉS FARRÉ,

---La fe que vino de Rusia. La revolución bolchevique y los españoles (19171931). Madrid, Biblioteca Nueva-UNED, 1999.

---“El impacto de la Revolución rusa en España, 1917-1922” en Javier TUSELL, Juan AVILÉS y Rosa PARDO (Eds.): La política exterior de España en el siglo XX. Madrid, Biblioteca Nueva, 2000.

- Tomás BORRÁS, checas de Madrid. Edición crítica de Álvaro LÓPEZ FERNÁNDEZ y Emilio PERAL VEGA. Madrid, Escolar y Mayo, 2016.

- Zira BOX: España, año cero: la construcción simbólica del franquismo. Madrid, Alianza, 2010.

- Julián CASANOVA, La venganza de los siervos. Rusia 1917. Barcelona, Crítica, 2017. 
- Assumpta CASTILLO CAÑIZ, "El forastero en la guerra civil española. Las dinámicas intra y extracomunitarias de la violencia en la retaguardia republicana," en Revista Universitaria de Historia Militar 6, vol. 3, 2014.

- Javier CERVERA GIL,

--- Madrid en guerra. La ciudad clandestina, 1936-1939. Madrid, Alianza, 2006.

---Contra el enemigo de la República desde la ley. Detener, juzgar y encarcelar en guerra. Madrid, Biblioteca Nueva, 2015.

- Rafael CRUZ,

--- “iLuzbel vuelve al mundo! Las imágenes de la Rusia Soviética y la acción colectiva en España”, en Rafael CRUZ y Manuel PÉREZ LEDESMA (eds.): Cultura y Movilización en la España contemporánea. Madrid, Alianza, 1997.

--- "Pensar la violencia colectiva europea en perspectiva histórica" en Javier MUÑOZ SORO, José Luis LEDESMA, Javier RODRIGO (coords.): Culturas y políticas de la violencia. España siglo XX, Siete Mares, Madrid, 2005.

- María de los Ángeles EGIDO LEÓN, "Del paraíso soviético al peligro marxista. La Unión Soviética en la España republicana (1931-1936)" en Cuadernos de Historia Contemporánea, nº 10, año 1988.

- Francisco ERICE, "El impacto de la revolución rusa en el movimiento obrero español: el surgimiento del PCE” en Juan ANDRADE y Fernando HERNÁNDEZ SÁNCHEZ (Eds.): 1917. La Revolución rusa cien años después. Madrid, Akal, 2017.

- Sebastiaan FABER, "Es la hora de la claridad dogmática". El impacto de la revolución rusa en la cultura política española” en Juan ANDRADE y Fernando HERNÁNDEZ SÁNCHEZ (Eds.), 1917. La Revolución rusa cien años después. Madrid, Akal, 2017.

- José María FARALDO, La Revolución rusa: Historia y memoria. Madrid, Alianza, 2017.

- Stuart FINKEL, "An Intensification of Vigilance: Recent Perspectives on the Institutional History of the Soviet Security Apparatus in the 1920s" en Kritika. Explorations in Russian and Eurasian History, 5 (2), 2004. 
- Sheila FITZPATRICK,

--- La Revolución rusa. Buenos Aires, Siglo XXI, 2005.

--- El equipo de Stalin. Los años más peligrosos de la Rusia soviética, de Lenin a Jrushchov. Barcelona, Crítica, 2016.

- Agustín de FOXÁ, Madrid de Corte a Checa. Salamanca, Jerarquía, 1938.

- Hugo GARCÍA,

---“Historia de un mito político. El peligro comunista en el discurso de las derechas españolas (1918-1936)" en Historia Social, nº 51, 2005.

--- "Relatos para una guerra. Terror testimonio y literatura en la España nacional," Ayer, 76, 4 (2009).

- Eduardo GONZÁLEZ CALLEJA,

---“La dialéctica de las pistolas: la violencia y la fragmentación del poder político durante la Segunda República," en Javier MUÑOZ SORO, José Luis LEDESMA, Javier RODRIGO (coords.): Culturas y políticas de la violencia. España siglo $X X$, Siete Mares, Madrid, 2005.

---En nombre de la autoridad. La defensa del orden público durante la Segunda República española (1931-1936). Granada, Comares, 2014.

- Gutmaro GÓMEZ BRAVO y Alejandro PÉREZ-OLIVARES, "Las lógicas de la violencia en la guerra civil. Balance y perspectivas historiográficas", Estudio Historia Contemporánea 32, Salamanca, Universidad de Salamanca, 2014.

- James HARRIS, El gran miedo. Una nueva interpretación del terror en la Revolución rusa. Barcelona, Crítica, 2017.

- José Luis LEDESMA,

- Los días de llamas de la revolución: violencia y política en la retaguardia republicana de Zaragoza durante la guerra civil, Institución Fernando el Católico, Zaragoza, 2004.

--- "«La santa ira popular» del 36: la violencia en guerra civil y revolución, entre cultura y política," en Javier MUÑOZ SORO, José Luis LEDESMA, Javier 
RODRIGO (coords.), Culturas y políticas de la violencia. España siglo XX, Siete Mares, Madrid, 2005.

--- "El 1936 más opaco: las violencias en la zona republicana durante la Guerra Civil y sus narrativas", en Historia Social, 58 (2007).

--- "Qué violencia para qué retaguardia, o la República en guerra de 1936", Ayer, 76, 4 (2009).

---"Del pasado oculto a un pasado omnipresente: Las violencias en la Guerra Civil y la historiografía reciente", Jerónimo Zurita. Revista de Historia, 84 (2009).

--- "Una retaguardia al rojo. Las violencias en la zona republicana" en Francisco ESPINOSA MAESTRE (Ed.), Violencia Roja y Azul. España, 1936-1950. Barcelona, Crítica, 2010.

--- "Sobre revoluciones, violencias y la España republicana en guerra," en Francisco MORENTE (Ed.), España en la crisis europea de entreguerras. República, fascismo y guerra civil. Madrid, La Catarata, 2011.

--- "¿Cuchillos afilados? De violencias, guerra civil y culturas bélicas en la España del primer siglo XX", en Jordi Canal, Eduardo González Calleja (eds.), Guerras civiles. Una clave para entender la Europa de los siglos XIX y XX, Casa de Velázquez, Madrid, 2012.

- José Luis MARTÍN RAMOS, "Del fin del ciclo de Octubre al Frente Popular" en Juan ANDRADE y Fernando HERNÁNDEZ SÁNCHEZ (Eds.), 1917. La Revolución rusa cien años después. Madrid, Akal, 2017.

- Arno J. MAYER, Las Furias. Violencia y terror en las revoluciones francesa y rusa. Zaragoza, Prensa de la Universidad de Zaragoza, 2014.

- Javier MUÑOZ SORO, José Luis LEDESMA, Javier RODRIGO (coords.), Culturas y políticas de la violencia. España siglo XX, Siete Mares, Madrid, 2005.

- Xosé M. NÚÑEZ SEIXAS, Camarada Invierno. Experiencia y memoria de la División Azul (1941-1945). Barcelona, Crítica, 2016. 
- Daniel OVIEDO SILVA y Alejandro PÉREZ-OLIVARES GARCíA, Madrid, una capital en guerra (1936-1948). Madrid, La Catarata, 2016.

- Paul PRESTON, El Holocausto español. Odio y exterminio en la Guerra Civil y después. Barcelona, Debate, 2011.

- Javier RODRIGO, Hasta la raíz. Violencia durante la guerra civil y la dictadura franquista. Madrid, Alianza Editorial, 2008.

- Julius RUIZ, El terror rojo. Madrid, 1936. Barcelona, Espasa, 2012.

- Jacques SADOUL, Cartas desde la revolución bolchevique. Madrid, Turner, 2016.

- Francisco SEVILLANO, Rojos. La representación del enemigo en la guerra civil. Madrid, Alianza, 2007.

- Maria THOMAS, La fe y la furia. Violencia anticlerical popular e iconoclastia en España, 1931-1936. Granada, Comares, 2014.

- Enzo TRAVERSO,

--- A sangre y fuego: de la guerra civil europea (1914-1945). Valencia, Universidad de Valencia, 2009.

--- La historia como campo de batalla. Interpretar las violencias del siglo XX. Buenos Aires, Fondo de Cultura Económica, 2012.

- Julián VADILLO MUÑOZ, Por el pan, la tierra y la libertad. El anarquismo en la Revolución rusa. Guadalajara, Volapük, 2017.

- Nicolas WERTH, Un Estado Contra su Pueblo. Violencia, Temores y Represiones en la Unión Soviética. Edición electrónica, 2011. http://www.laeditorialvirtual.com.ar.

- Serge WOLIKOW, "La creación de la Komintern y la onda expansiva de la revolución en Europa: interacciones y desfases", en Juan ANDRADE y Fernando HERNÁNDEZ SÁNCHEZ (Eds.), 1917. La Revolución rusa cien años después. Madrid, Akal, 2017. 